\title{
LOCKBRICK MODULAR BETON UNTUK ALTERNATIF BAHAN DINDING YANG MEMENUHI MUTU SNI DENGAN BIAYA MURAH
}

\author{
Chundakus Habsya, Anis rahmawati, Sri Sumarni. \\ Program Studi Pendidikan Teknik Banguan FKIP UNS Surakarta \\ Email: habsyasl.2004@gmail.com
}

\begin{abstract}
ABSTRAK
Lockbrick modular merupakan hasil desain prapabrikasi komponen bangunan gedung. Lockbrick modular merupakan bahan dinding, yang pelaksanaannya tidak membutuhkan spesi pengikat, melainkan cukup disusun dan dirangkai, masing-masing saling mengunci oleh karena sisi sambungan berbentuk sambungan jantan betina. Lockbrick modular dapat untuk berbagai tinggi dan lebar dinding sesuai kelipatan dimensi modul $15 \mathrm{~cm}$. Bagian dalam dinding Lockbrick modular ada lubang $7 \mathrm{~cm} \times 7 \mathrm{~cm}$ menerus dari atas ke bawah berfungsi mengurangi bobot, penghambat panas, untuk perkuatan dinding, tempat pipa air bersih, dan kabel listrik. Tujuan penelitian untuk mengetahui kuat tekan, daya serap air lockbrick modular yang memenuhi syarat mutu $S N I$, dan biaya per- $m^{2}$ dinding yang menggunakan lockbrick. Metode penelitian eksperimen dengan uji kuat tekan, daya serap air dan menghitung biaya dinding menggunakan acuan Harga Satuan Pekerjaan Bahan dan Upah Pekerjaan Konstruksi Propinsi Jawa Tengah Untuk Kota Surakarta. Prosentase campuran adalah 1 pc : 4 agregat, yang terdiri dari pasir : ladu : kerikil dengan berbagai variasi komposisi. Masingmasing komposisi dicetak 3 lockbrick modular. Hasil penelitian adalah produk lockbrick modular memenuhi syarat mutu kuat tekan dan daya serap air SNI bata beton berlubang mutu II, III dan IV. Produk lockbrick modular dengan kuat tekan optimal 6.84 MPa, daya serap air $19.55 \%$ memenuhi syarat mutu II. Biaya dinding lockbrick modular per- $m^{2}, 24 \%$ lebih murah dari biaya dinding batako
\end{abstract}

Kata Kunci: lockbrick, modular, beton, dinding

\section{PENDAHULUAN}

Pembangunan bidang sipil mengalami peningkatan sangat pesat, seperti pembangunan gedung, jembatan, tower, maupun bidang konstruksi lainnya. Pada kegiatan pembangunan tersebut, beton menjadi salah satu bahan yang diminati dalam pembuatan struktur bangunan. Hal ini dikarenakan beton memiliki banyak kelebihan, diantaranya harga relatif murah, memiliki kuat tekan tinggi, dengan bentuk dapat disesuaikan dengan rencana, ketahanan yang baik terhadap cuaca dan lingkungan sekitar.

Salah satu komponen pembangunan gedung adalah dinding karena dinding pembatas ruang diperlukan di semua bagian bangunan gedung. Bahan dinding biasanya menggunakan batu bata atau batako yang membutuhkan spesi pengikat, plester finishing permukaan luar. Penggunaan batu bata atau batako membutuhkan waktu relatif lama, biaya dinding mahal. Keadaan demikian akibat belum ada bata beton modular berpengunci, mudah dan cepat dalam pembuatan dinding, tidak membutuhkan keterampilan tukang tinggi dan biaya per- $\mathrm{m}^{2}$ yang lebih murah.

Prapabrikasi komponen dinding yang telah ada antara lain temuan Nagy, et al (2012), Modular Concrete Building; Yaitu prapabrikasi komponen bangunan yang terdiri dari komponen kolom, balok, panel lantai, panel dinding, dan panel atap yang terbuat dari beton. Dalam prapabrikasi tersebut panel dinding berdimensi besar, yaitu selebar bentang antar kolom, setinggi ruang atau dari panel lantai sampai panel atap. Pada panel dinding tersebut sudah didesain lubang untuk pintu, dan lubang untuk ventilasi. Perkuatan hubungan antara panel dinding dengan balok, menggunakan pen baja, mur baut yang dilengkapi dudukan plat baja, pada tempat yang telah disediakan. Pada rongga antara 
lubang pada panel dinding atau komponen balok dengan mur baut diisi semacam karet penutup (seal). Demikian juga perkuatan hubungan antara panel dinding dengan panel penutup atap, menggunakan pen baja, mur baut dilengkapi dudukan plat baja serta rongga antara lubang pada panel dinding dan panel penutup atap dengan mur baut diisi semacam karet penutup (seal).

Bentuk panel dinding yang lain adalah Concrete Panel Consctruction System (Nick Dilorenzo (2011), yaitu berupa bidang panel beton bangunan yang berada di dua sisi, dimana bagian dalamnya ada rangka yang berfungsi tempat menempel bidang panel dan perkuatan antar unit panel dinding. Masingmasing rangka panel bagian tepi ada beberapa lubang dengan jarak sama, berguna untuk mengikatkan antar panel yang berdekatan. Panel ini berdimensi cukup besar, bahkan ada satu bidang untuk pembatas antar dua ruang dalam bangunan gedung

Material dinding yang mirip dengan batu bata atau batako adalah Modular Building Materials (Scott Simmons, 2000), yaitu komponen dinding dalam bentuk bata saling mengunci, kemiripannya dengan batako adalah pada bentuk bata segi empat memanjang, bagian dalam ada lubang. Sisi sambungan bata ini memiliki bentuk sambungan jantan dan betin, Perbedaannya adalah pada sambungan vertikal antar bata menggunakan mur baut yang dimasukkan dalam lubang dalam bata, serta adanya alur cekungan di sisi atas - bawah bata untuk diisi tangkai baja dan spesi beton sebagai pengikat horizontal antar bata.

Salah satu batu bata di India adalah Bata Interlock yang terbuat dari tanah (soi) dan semen, dengan kandungan semen 6 $10 \%$. Kuat tekan yang diperoleh berkisar antara 7,73 - 12,38 Mpa, berat jenis 1800 $\mathrm{kg} / \mathrm{m}^{3}$, daya serap air 13,56 - 18.02\% (Mahsa Chavoshi, 2011).

Sedangkan di Indonesia antara lain bahan dinding beton yang dihasilkan peneliti Pusltbang Bandung yaitu interlockblock. Interlockblock adalah bata dengan kedua sisi tegaknya beralur dan berlidah. Siar tegak dinding pasangan ini tidak perlu diberi adukan. Adukan tipis hanya diberikan pada siar horizontal (WS. Witarso, 2007).

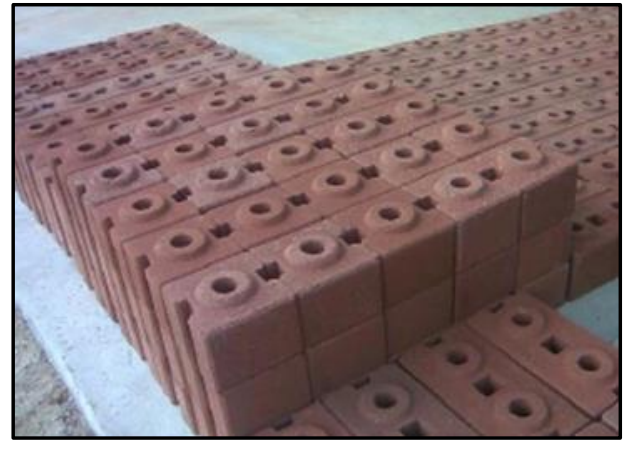

Gambar 1. Soil-Cement interlocking block Sumber: Masha Chavoshi, 2011

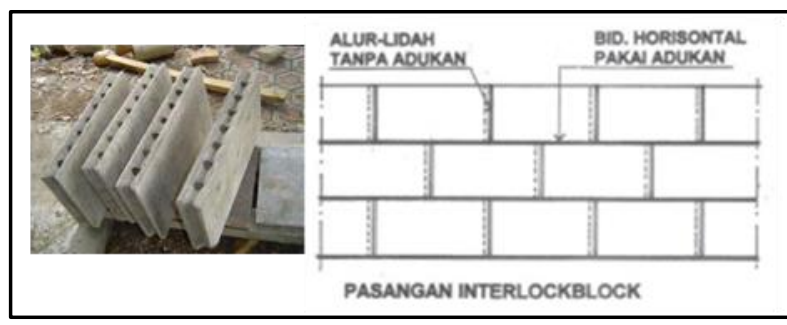

Gambar 2. Bentuk dan pemasangan interlockblock Sumber: WS. Witarso, 2007

Bata interlock adalah bahan dinding yang sisi sambungannya berbentuk tonjolan dan lekukan sehingga pemasangnya tidak membutuhkan adukan spesi untuk merekatkan bata. Bagian dalam bata interlock ada rongga dapat berfungsi sebagai insulasi termal maupun mengurangi kebisingan. Kuat tekan bata interlock berkisar 5.3 Mpa (Kaskus, http://archive.kaskus.co.id/thread/908330/377 0, 2015).

Alternatif bahan dinding selain batu bata, batako interlockblock adalah hasil desain prapabrikasi komponen dinding bangunan gedung berupa bata moduler berpengunci yang selanjutnya disebut lockbrick modular. Lockbrick modular Tlb-1, Tlb-2, berdimensi modular yang dapat untuk berbagai tinggi dan lebar dinding sesuai kelipatan dimensi modul $15 \mathrm{~cm}$.

Lockbrick modular sebagai bahan alternatif dinding, berdimensi kecil seperti dimensi batako atau hollow brick, masingmasing sisi didesain sambungan jantan dan betina (tongue and groove), dengan pelaksanaan pembuatan dinding cukup disusun dan dirangkai, tidak membutuhkan spesi pengikat. Bagian tengah lockbrick modular ada dua lubang (Tlb-1), satu lubang (Tlb-2), yang masing-masing lubang 
berdimensi $7 \mathrm{~cm} \times 7 \mathrm{~cm}$. Lubang dalam dinding lockbrick modular menerus dari atas ke bawah, dapat untuk perkuatan dinding, tempat pipa saluran air bersih dan kabel listrik (Habsya 2010).

Lockbrick modular telah terdaftar paten dengan judul Bata Moduler Berpengunci Untuk Dinding Bangunan Gedung, No. S00201401680, Tanggal 21 Maret 2014.

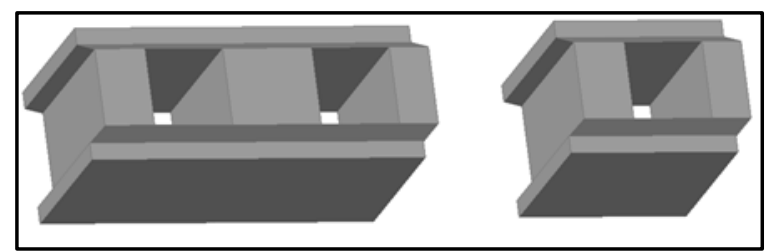

Gambar 3. Bentuk Lockbrick Modular Tlb-1 dan Tlb-2 Sumber: Habsya, 2010

Pengembangan alternatif bahan dinding bangunan gedung banyak dilakukan para peneliti. Baik dari perguruan tinggi maupun dari lembaga penelitian yang lain. Dalam penelitian ini akan dikaji lockbrick modular untuk dapat digunakan sebagai alternatif material dinding, yang akan memberikan kemudahan bagi masyarakat, developer, Perum Perumnas dalam membuat dinding bangunan rumah atau bangunan gedung lainnya.

\section{TUJUAN DAN RUANG LINGKUP}

Penelitian ini merupakan pengembangan material bangunan yaitu lockbrick moduler sebagai alternatif bahan untuk dinding yang terbuat dari beton.

Penelitian diadakan dengan maksud mengkaji alternatif bahan dinding yang tidak membutuhkan spesi perekat antar lockbrick dan kelayakan mekanis, biaya per $\mathrm{m}^{2}$. Kelayakan mekanis dilihat dari kuat tekan dan daya serap air yang memenuhi mutu SNI 030349-1989.

Dalam Standar Nasional Indonesia (SNI) 03-0349-1989, tentang Bata Beton untuk Pasangan Dinding Berlubang, ada klasifikasi tingkat mutu I, II, III, dan IV. Dalam paper ini akan mengacu kepada syarat fisis tingkat mutu bata beton berlubang, apakah hasil eksperimen kuat tekan dan daya serap air lockbrick dengan komposisi bahan 1 pc : 4 agregat memenuhi mutu I, II, III atau IV ?

Selain itu juga akan dihitung biaya $1 \mathrm{~m}^{2}$ dinding lockbrick, dibandingkan dengan biaya dinding menggunakan batako (hollow brick) tebal $10 \mathrm{~cm}$. Kelayakan biaya ditinjau mulai dari kapasistas produksi mesin, harga perunit lockbrick dan biaya per $\mathrm{m}^{2}$ dinding menggunakan lockbrick dibandingkan dengan dinding batu bata.

\section{TINJAUAN PUSTAKA \\ Standar Nasional Indonesia (SNI)}

Beberapa SNI yang dijadikan rujukan dalam studi ini, antara lain:

SNI 03-0349-1989: adalah standar Bata Beton untuk Pasangan Dinding, yang mengatur persyaratan penampang bata beton pejal atau berlubang, persyaratan kuat tekan dan daya serap air.

SNI 6897:2008: SNI ini menentukan indek bahan dan indek upah untuk menghitung biaya pelaksanaan satuan pekerjaan tertentu, dalam hal ini khusus dicuplik jenis pekerjaan pasangan dinding bata merah, dan pasangan dinding hollow block, yang akan digunakan sebagai pembanding dengan pekerjaan pasangan dinding lockbrick.

\section{Kuat Tekan}

Kekuatan tekan merupakan salah satu kinerja beton. Kekuatan tekan adalah kemampuan beton untuk menerima gaya tekan per satuan luas

Rumus kuat tekan $\mathrm{P}=\mathrm{F} / \mathrm{A}$

Dengan :

$\mathrm{F}$ = gaya maksimum mesin tekan, $\mathrm{N}$

$A=$ luas penampang yang diberi tekanan, $\mathrm{cm}^{2}$

$\mathrm{P}=$ kuat tekan $\mathrm{N} / \mathrm{cm}^{2}$

\section{Daya Serap Air}

Daya serap merupakan kemampuan agregat untuk menyerap persentase berat air di dalam air. Besar kecilnya penyerapan tergantung dari pori atau rongga yang terdapat pada beton. Semakin banyak pori yang terkandung dalam beton maka semakin besar pula penyerapan airnya sehingga ketahanannya akan berkurang

$$
\begin{aligned}
& \text { Rumus daya serap air (WA) }=\frac{M j-M k}{M k} \ldots \\
& \text { Dengan : } \\
& \text { WA = Daya serap air (\%) } \\
& \begin{array}{ll}
M j \quad=\text { Massa jenuh air (gram) } \\
M k \quad=\text { Massa sampel kering (gram) }
\end{array}
\end{aligned}
$$




\section{Perawatan Beton}

Perawatan beton dilakukan setelah mengeras (final setting), di letakkan pada tempat tidak kena sinar matahari langsung agar proses hidrasi selanjutnya berjalan secara berangsur, proses kehilangan air tidak terlalu cepat dan tidak terjadi retak.

Kuat tekan beton berbanding lurus dengan bertambahnya umur beton. Menurut Dipohusodo (1994), umumnya pada umur 7 hari kuat tekan beton mencapai $70 \%$ dan pada umur 14 hari mencapai $85 \%$ - 95\% dari kuat tekan beton umur 28 hari.

\section{METODE PENELITIAN}

Penelitian ini bersifat kuantitatif melalui pendekatan eksperimen, dalam bentuk uji material. Parameter yang dicari dalam penelitian ini adalah kuat tekan, daya serap air, serta biaya dinding lockbrick per meter persegi. Kuat tekan dan daya serap air adalah parameter kelayakan lockbrick dari aspek mekanis sedangkan biaya pembuatan dinding adalah aspek kelayakan ekonomi.

Penelitian dilakukan dengan memperlakukan produk dalam kondisi terkontrol dengan urutan kegiatan sistematis sehingga diperoleh data yang dapat untuk mengambil kesimpulan.

\section{Parameter Penelitian}

\section{a. Uji Kuat Tekan Lockbrick}

Benda uji dalam bentuk lockbrick modular Tlb-1 dan Tlb-2. Dimensi benda uji tebal $12 \mathrm{~cm}$, tinggi $15 \mathrm{~cm}$ dan panjang $30 \mathrm{~cm}$ (Tlb-1) dan $15 \mathrm{~cm}$ (Tlb-2). Pengujian dilakukan di Laboratorium Beton PTB UNS Pabelan Surakarta.

Uji kuat tekan dilakukan pada umur 28 hari, dimana kekuatan beton telah mencapai $100 \%$. Untuk meratakan beban lockbrick pada waktu uji tekan maka dibuat plat baja untuk tapak atas dan bawah dengan bentuk menyesuaikan bentuk tapak atas - bawah lockbrick.

\section{b. Uji Daya Serap Air Lockbrick}

Benda uji dalam bentuk lockbrick modular Tlb-1. Pengujian daya serap air dilakukan di Laboratorium Beton PTB UNS Pabelan Surakarta.

\section{c. Biaya Pembuatan Dinding Lockbrick.}

Dalam SNI tentang Analisa Biaya Konstruksi telah ditentukan indek bahan dan indek upah untuk menghitung biaya pelaksanaan satuan pekerjaan tertentu. Dalam hal ini akan dicuplik 2 jenis pekerjaan dinding, yaitu pekerjaan pasangan dinding bata merah, dan pasangan dinding conblock, yang akan digunakan sebagai pembanding dengan pekerjaan pasangan dinding lockbrick modular.

Selain itu penghitungan juga didasarkan pada Harga Satuan Pekerjaan dan Upah Pekerjaan Konstruksi Propinsi Jawa Tengah, Kota Surakarta, tahun 2015.

Tabel 1. Dimensi Lockbrick Modular

\begin{tabular}{|c|c|c|c|c|}
\hline \multirow{2}{*}{ Tipe } & \multicolumn{3}{|c|}{ Dimensi } & \multirow{2}{*}{ Keterangan } \\
\hline & $\mathrm{L}$ & W & $\mathrm{H}$ & \\
\hline Tbl-1 & 30 & 12 & 15 & $\begin{array}{l}\text { Memiliki } 2 \text { lubang, } \\
\text { masing-masing } 7 \times 7 \mathrm{~cm}\end{array}$ \\
\hline Tbl-2 & 15 & 12 & 15 & $\begin{array}{l}\text { Memiliki } 1 \text { lubang, } \\
\text { masing-masing } 7 \times 7 \mathrm{~cm}\end{array}$ \\
\hline
\end{tabular}

Keterangan : $\mathrm{L}=$ panjang, $\mathrm{W}=$ tebal, $\mathrm{H}=$ tinggi Sumber : Habsya, 2010

Perhitungan harga lockbrick didasarkan kepada kapasitas produksi mesin, biaya material, biaya tenaga kerja, biaya beban listrik dan jasa produksi.

\section{Kelayakan Lockbrick Modular Beton Berdasarkan SNI 03-0349-1989}

Lockbrick modular termasuk dalam katagori bata beton berlubang. Dalam SNI Bata beton berlubang disyaratkan yaitu:

- Memiliki luas penampang lubang lebih dari $25 \%$ luas penampang batanya dan volume lubang lebih dari $25 \%$ volume bata seluruhnya.

- Memiliki kuat tekan dan daya serap air seperti pada tabel 2:

Tabel 2. Persyaratan Kuat Tekan, Daya Serap Air

\begin{tabular}{|c|c|c|c|c|c|}
\hline \multirow[t]{2}{*}{ Syarat Fisis } & \multirow[t]{2}{*}{$\begin{array}{l}\text { Sa } \\
\text { tu } \\
\text { an }\end{array}$} & \multicolumn{4}{|c|}{$\begin{array}{c}\text { Tingkat Muutu Bata } \\
\text { Beton Berlubang }\end{array}$} \\
\hline & & 1 & II & III & IV \\
\hline $\begin{array}{l}\text { Kuat tekan bruto } \\
\text { rata-rata minimal }\end{array}$ & $\mathrm{MPa}$ & 7,0 & 5,0 & 3,5 & 2,0 \\
\hline $\begin{array}{l}\text { Kuat tekan bruto } \\
\text { masing-masing } \\
\text { produk }\end{array}$ & $\mathrm{MPa}$ & 6,5 & 4,5 & 3,0 & 1,7 \\
\hline Penyerapan air & $\%$ & 25 & 35 & - & - \\
\hline
\end{tabular}




\section{Pembuatan Lockbrick modular}

\section{a. Komposisi Bahan}

Material untuk mencetak lockbrick Tlb-1 dan Tlb-2 adalah Semen (PC), pasir beton lepas saringan $5 \mathrm{~mm}$ (psr), kerikil $6-10 \mathrm{~mm}$ (psr) dan abu (ladu) pecahan batu mess 100. Kerikil yang digunakan berdimensi kecil untuk mendapatkan beton yang padat pada semua bagian lockbrick, terutama pada sisi dinding lockbrick tebal $25 \mathrm{~mm}$.

Komposisi material yang digunakan 1 pc : 4 agregat, dengan variasi agregat seperti pada tabel 3.

Tabel 3. Prosentase Agregat

\begin{tabular}{|c|c|c|}
\hline No. & $\begin{array}{c}\text { Sampel } \\
\text { Lockbrick }\end{array}$ & Prosentase Agregat \\
\hline 1 & Tlb-1 & $10 \%$ psr, $50 \%$ ladu, $40 \% \mathrm{krl}$ \\
\hline 2 & Tlb-1 & $10 \%$ psr, $40 \%$ ladu, $50 \%$ krl \\
\hline 3 & Tlb-1 & $10 \%$ psr, 30\% ladu, 60\% krl \\
\hline 4 & Tlb-1 & $20 \%$ psr, 50\% ladu, 30\% krl \\
\hline 5 & Tlb-1 & $20 \%$ psr, $40 \%$ ladu, $40 \% \mathrm{krl}$ \\
\hline 6 & Tlb-1 & $20 \%$ psr, 30\% ladu, 50\% krl \\
\hline 7 & Tlb-1 & $20 \%$ psr, $20 \%$ ladu, $60 \% \mathrm{krl}$ \\
\hline 8 & Tlb-1 & $30 \%$ psr, 50\% ladu, 20\% krl \\
\hline 9 & Tlb-1 & $30 \%$ psr, 30\% ladu, $40 \% \mathrm{krl}$ \\
\hline 10 & Tlb-1 & $30 \%$ psr, $20 \%$ ladu, 50\% krl \\
\hline 11 & Tlb-1 & $30 \%$ psr, $10 \%$ ladu, $60 \% \mathrm{krl}$ \\
\hline 12 & Tlb-1 & $40 \%$ psr, $20 \%$ ladu, $40 \% \mathrm{krl}$ \\
\hline 13 & Tlb-1 & $40 \%$ psr, $10 \%$ ladu, $50 \%$ krl \\
\hline 14 & Tlb-1 & $50 \%$ psr, 30\% ladu, 20\% krl \\
\hline 15 & Tlb-1 & $50 \%$ psr, $20 \%$ ladu, 30\% krl \\
\hline 16 & Tlb-1 & $50 \%$ psr, $10 \%$ ladu, $40 \%$ krl \\
\hline
\end{tabular}

Sumber: Penelitian 2014

\section{b. Pengadukan campuran beton}

Pengadukan campuran beton menggunakan mixer untuk campuran beton kering seperti mixer untuk mencetak paving block. Pertama pengadukan semen dan agregat sampai diperoleh campuran homogen, dan berikutnya tambahkan air sesuai rencana campuran. Pengadukan setelah ditambahkan air dilakukan sampai homogen. Kemudian adukan yang telah homogen dimasukkan dalam cetakan bertahap sampai penuh.

\section{c. Cetakan lockbrick modular}

Cetakan lockbrick modular terdiri dari alas, cetakan dan tutup cetakan. Alas cetakan dari multipleks dan papan kayu jati yang telah dibentuk sesuai bentuk sambungan betina lockbrick.
Cetakan dan tutup cetakan terbuat dari plat baja tebal $4-6 \mathrm{~mm}$ dan pipa baja diameter $18 \mathrm{~mm}$.

\section{d. Mekanisme Kerja Mesin Pencetak}

Mekanisme mesin yang digunakan dalam membuat lockbrick adalah tekan dan getar. Tekan menggunakan tutup cetakan dengan gaya gravitasi, getar diperoleh dari motor penggerak dikonversi menjadi getar. Mekanisme getar, berfungsi mendistribusikan adukan semen ke sudut-sudut cetakan, mengeluarkan gelembung udara dalam adukan semen, sehingga padat. Mekanisme tekan, berfungsi untuk meratakan permukaan atas produk.

\section{e. Perawatan}

Perawatan produk lockbrick modular dilakukan dengan meletakan di rak dalam ruangan beratap sehingga tidak kena sinar matahari langsung. Setiap hari selama 10 hari pertama produk di siram dengan air. Produk akan memperoleh kekuatan $100 \%$ pada umur perawatan 28 hari. Uji kuat tekan dan daya serap air dilakukan setelah lockbrick 28 hari.

\section{f. Sampel Uji Lockbrick}

Sampel lockbrick yang akan diuji kuat tekan dan daya serap air adalah lockbrick tipe Tlb-1. Masing-masing komposisi 3 sampel. Jumlah sampel Tlb-1 = $3 \times 16$ komposisi $\times 2$ obyek uji = 96 buah.

\section{HASIL DAN PEMBAHASAN Lockbrick sebagai bata beton berlubang.}

Luas penampang lockbrick Tlb-1 $262 \mathrm{~cm}^{2}$, luas penampang lubang $98 \mathrm{~cm}$, atau $37 \%$ dari luas panampang Tlb-1 (Gambar 4). Luas penampang Tlb-2 $131 \mathrm{~cm}$, luas penampang lubang $49 \mathrm{~cm}$, atau $37 \%$ dari luas penampang lockbrick Tlb-2 (Gambar 5).

Berdasarkan SNI 03-0349-1989 bahwa katagori bata beton berlubang memilki luas penampang lubang lebih dari $25 \%$, maka lockbrick modular Tlb-1 dan Tlb-2 memenuhi katagori tersebut. 


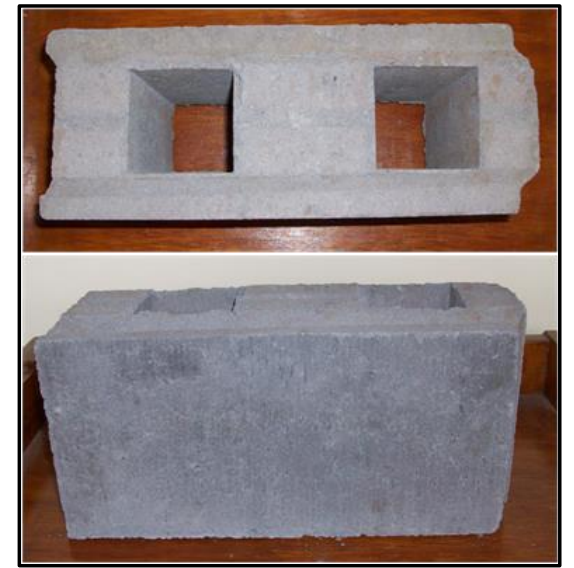

Gambar 4. Produk lockbrick beton Tlb-1 Sumber: Habsya, 2010

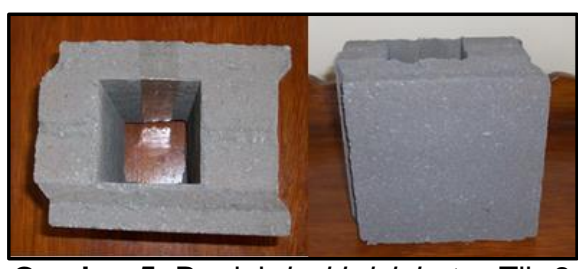

Gambar 5. Produk lockbrick beton Tlb-2 Sumber: Habsya, 2010

Kuat Tekan dan Daya Serap Air Lockbrick

Hasil uji kuat tekan dan daya serap air ditampilkan pada tabel berikut:

Tabel 4. Kuat Tekan dan daya serap air

\begin{tabular}{ccc}
\hline $\begin{array}{c}\text { No } \\
\text { Sampel }\end{array}$ & $\begin{array}{c}\text { Rata-rata Kuat } \\
\text { Tekan (MPa) }\end{array}$ & $\begin{array}{c}\text { Rata-rata Daya } \\
\text { Serap Air (\%) }\end{array}$ \\
\hline 1 & 3,437 & 23,46 \\
\hline 2 & 4,097 & 22,73 \\
\hline 3 & 5,073 & 21,68 \\
\hline 4 & 2,750 & 24,72 \\
\hline 5 & 3,623 & 22,03 \\
\hline 6 & 4,176 & 22,54 \\
\hline 7 & 6,247 & 19,83 \\
\hline 8 & 2,529 & 24,68 \\
\hline 9 & 3,982 & 22,81 \\
\hline 10 & 5,397 & 21,24 \\
\hline 11 & 6,837 & 19,55 \\
\hline 12 & 3,747 & 22,87 \\
\hline 13 & 5,943 & 20,78 \\
\hline 14 & 2,840 & 24,83 \\
\hline 15 & 3,250 & 23,31 \\
\hline 16 & 4,297 & 22,14 \\
\hline
\end{tabular}

\section{Mutu Lockbrick berdasarkan SNI}

Data tabel 4 dan gambar 5 menunjukkan bahwa kuat tekan lockbrick semua komposisi agregat memenuhi kuat tekan mutu II, III, dan IV SNI 03-0349-1989. Angka tersebut lebih rendah dari kuat tekan batu bata India (interlock brick). Perbedaan hasil kuat tekan tersebut disebabkan antara lain perbedaan komposisi campuran, proses pencetakan, termasuk didalamnya adalah kemampuan getar dan tekan mesin pencetak yang digunakan, proses perawatan serta bentuk bata. Perbedaan bentuk bata antara lain dari sisi dimensi tinggi bata India lebih kecil dari lockbrick, lubang bata India selinder dengan luas relatif kecil, sedangkan lubang lockbrick berbentuk persegi dengan luas lebih besar.

Ragam angka kuat tekan lockbrck pada gambar 6, menunjukkan bahwa semakin sedikit prosentase ladu dan semakin banyak prosentase kerikil menunjukkan angka kuat tekan semakin besar.

Data tabel 5 dan gambar 7 menunjukkan bahwa daya serap air semua komposisi agregat lebih kecil dari $25 \%$, memenuhi syarat mutu I SNI 03-0349-1989. Daya serap air lockbrick tersebut lebih besar dari batu bata India. Perbedaan angka tersebut antara lain disebabkan perbedaan komposisi bahan pembentuk bata serta perbedaan kuat tekan. Semakin padat material pembentuknya biasanya semakin tinggi kuat tekannya dengan daya serap air semakin rendah.

Gambar 7 juga menunjukkan bahwa semakin sedikit prosentase ladu dan semakin banyak prosentase kerikil menunjukkan angka daya serap air semakin rendah.

Kuat Tekan (MPa)

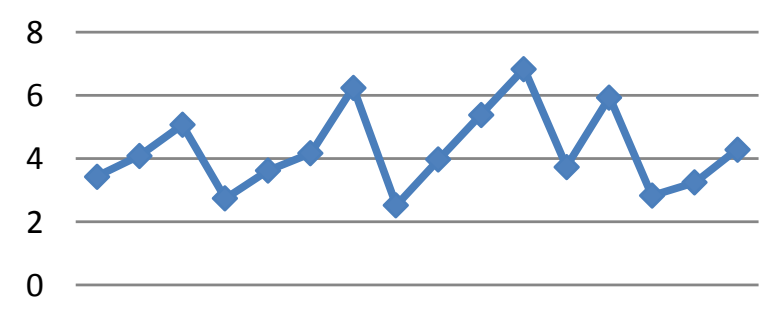

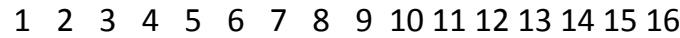

$\checkmark$ Kuat Tekan

Gambar 6. Kuat Tekan berbagai komposisi agregat

Sumber: Analisis penelitian 2014 
Daya Serap Air (\%)

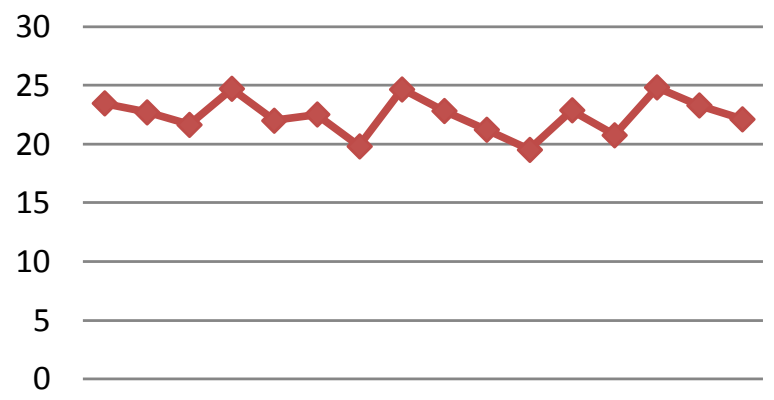

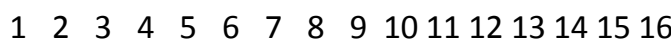

$\longrightarrow$ Daya Serap Air

Gambar 7. Daya Serap air berbagai komposisi agregat

Sumber: Analisis penelitian 2014

Data tabel 4 dan gambar 7 menunjukkan bahwa kuat tekan dan daya serap air diatas menunjukkan bahwa semua komposisi yang digunakan untuk mencetak produk lockbrick secara mekanis layak dan memenuhi persyaratan SNI yang ada.

Gambar 7 menunjukan bahwa nilai optimal kuat tekan sebesar $6,84 \mathrm{MPa}$ pada komposisi sampel nomor 11, dengan daya serap air $19,55 \%$. Dari gambar dapat dilihat bahwa semakin tinggi angka kuat tekan, semakin rendah daya serap air atau angka kuat tekan berbanding terbalik dengan angka daya serap air.

Upaya mengurangi limbah sampah dengan memanfaatkan abu pembakaran sampah Putri Cempo Karanganyar sebagai bahan tambah agregat dalam penelitian lockbrick pernah dilakukan. Upaya tersebut dilakukan oleh Yoga (2013) dengan perbandingan 1 pc : 7 agregat. Untuk komposisi $0 \%$ abu pembakaran sampah, $100 \%$ pasir menghasilkan kuat tekan 4,3 $\mathrm{MPa}$ (mutu III SNI), dan komposisi 15\% abu sampah, $85 \%$ pasir menghasilkan kuat tekan 2.77 MPa. Untuk komposisi abu pembakaran sampah $20 \%$ dan 25\% menghasilkan kuat tekan yang tidak memenuhi syarat SNI. Sedangkan angka daya serap air semua komposisi tersebut diatas memenuhi syarat SNI.
Kuat Tekan \& Daya Serap Air

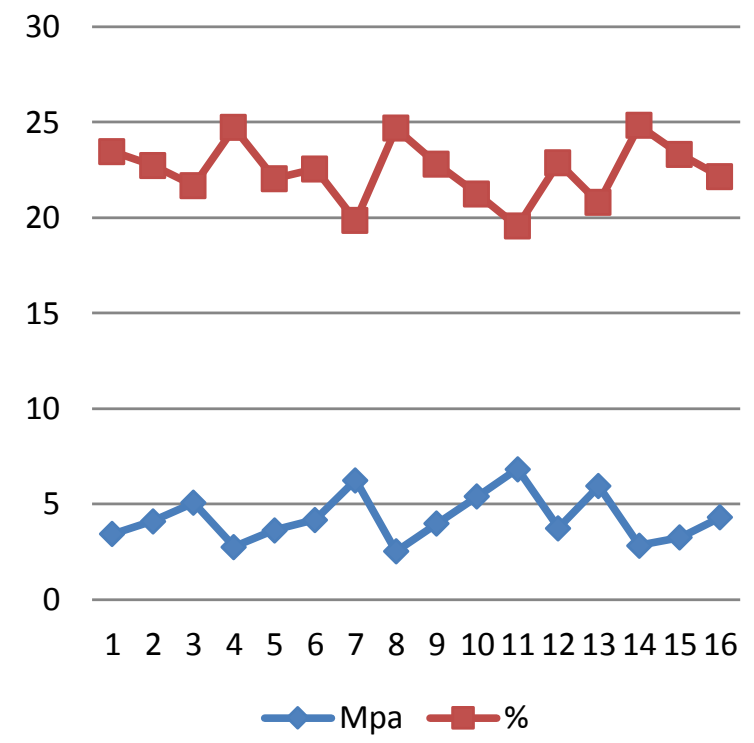

Gambar 8. Kuat tekan dan data serap air berbagai komposisi agregat.

Sumber: Analisis penelitian 2014

Kuat tekan lockbrick dengan bahan tambah abu pembakaran sampah 15\% termasuk dalam katagori mutu kuat tekan IV, yaitu untuk dinding partisi, tidak dapat untuk dinding pemikul. Angka-angka tersebut menunjukkan bawa upaya pemanfaatan limbah abu pembakaran sampah tidak signifikan mengurangai limbah yang ada.

\section{Biaya Pembuatan Dinding Lockbrick}

Untuk menghitung biaya pembuatan dinding lockbrick diperlukan data kapasitas produksi mesin, kebutuhan material, dan harga satuan pekerjaan bahan dan upah. Kapasitas produksi mesin perhari diperoleh selama uji coba produksi di laboratorium PTB FKIP UNS, yaitu menyangkut waktu masingmasing proses produksi, dan waktu efektif produksi.

Tabel 5. Kapasitas Produksi Mesin

\begin{tabular}{|l|c|}
\hline \multicolumn{1}{|c|}{ Keterangan } & Menit \\
\hline Waktu kerja hari $(7.0-16.00)$ & 510 \\
\hline $\begin{array}{l}\text { Persiapan awal produksi dan } \\
\text { merapikan tempat sore hari }\end{array}$ & 35 \\
\hline Waktu istirahat siang & 90 \\
\hline Waktu efektif produksi sekali cetak & 4 \\
\hline $\begin{array}{l}\text { Waktu diperlukan lockbrik } \\
\text { menghasilkan 2 unit lo }: 4) \times 2=\end{array}$ & 192.5 \\
\hline Kapasitas produksi mesin $(385: 5$ \\
\hline
\end{tabular}


Tabel 6. Harga lockbrick untuk mencetak 192 unit

\begin{tabular}{|l|l|r|r|}
\hline Ket & Jml & Rupiah & Jml (Rp) \\
\hline Semen & $372,3 \mathrm{~kg}$ & $1.250,--$ & $465.388,-$ \\
\hline Pasir & $446,8 \mathrm{~kg}$ & $114,-$ & $50.932,-$ \\
\hline Ladu & $297,8 \mathrm{~kg}$ & $74,-$ & $22.041,-$ \\
\hline Kerikil & $744,6 \mathrm{~kg}$ & $148,-$ & $110.204,-$ \\
\hline Air & $121,0 \mathrm{Itr}$ & & 0 \\
\hline Biaya material untuk 192 unit & $\mathbf{6 4 8 . 5 6 4 , - -}$ \\
\hline
\end{tabular}

Tabel 7. Tenaga kerja perhari

\begin{tabular}{|l|r|}
\hline 1 orang operator mesin pencetak & $70.000,-$ \\
\hline 1 orang operator mixer & $60.000,-$ \\
\hline Pembantu tukang & $50.000,-$ \\
\hline Biaya tenaga kerja & $\mathbf{1 8 0 . 0 0 0 , -}$ \\
\hline Biaya listrik (350 kw x 375) & $\mathbf{1 3 1 . 2 5 0 , -}$ \\
\hline Biaya produksi 192 unit/hari & $959,814,-$ \\
\hline Biaya produksi 1 unit lockbrick & $4.986,-$ \\
\hline Jasa produksi 15\% & $748,-$ \\
\hline Harga per unit lockbrick & $5.734,-$ \\
\hline Harga perunit dibulatkan & $5.750,-$ \\
\hline
\end{tabular}

\section{Biaya pembuatan dinding $\mathrm{m}^{2}$}

Peritungan biaya material dan tenaga didasarkan analisa sesuai SNI dan Daftar Harga dan Upah yang dikeluarkan Dinas PU Jawa Tengah untuk Kota Surakarta.

Tabel 8. Biaya dinding lockbrick $1 \mathrm{~m}^{2}$

\begin{tabular}{|l|l|l|r|}
\hline \multicolumn{3}{|l|}{ Biaya dinding lockbrick $\mathbf{~ m}^{2}$} & 164.811,-- \\
\hline Lockbrick & 22,22 & $5.750,-$ & $127.778,-$ \\
\hline Tenaga pasang & & & $11.750,-$ \\
\hline 0,1 pekerja & 0,16 & 45.000 & $7.200,-$ \\
\hline 0,05 tukang bt & 0,06 & 60.000 & $3.600,-$ \\
\hline $\begin{array}{l}\text { 0,005 kepala } \\
\text { tukang }\end{array}$ & 0,006 & 65.000 & $390,-$ \\
\hline 0,005 Mandor & 0,008 & 70.000 & $560,-$ \\
\hline Plesteran 1 pc:3pp, 5 mm, 2 rmuka & $25.283,-$ \\
\hline
\end{tabular}

Tabel 9. Biaya dinding batu bata $1 \mathrm{~m}^{2}$

\begin{tabular}{|c|c|}
\hline Biaya dinding batu bata $1 \mathrm{~m}^{2}$ & 166.003,- \\
\hline Bahan dinding (5x1x22), $1 \mathrm{pc}: 3 \mathrm{pp}$ & 61.113,-- \\
\hline Tenaga pasang dinding & 21.200 \\
\hline Plesteran 1pc:3pp, $15 \mathrm{~cm}, 2$ muka & $83.690,-$ \\
\hline
\end{tabular}

Tabel 10. Biaya dinding hollowblock $1 \mathrm{~m}^{2}$

\begin{tabular}{|l|r|}
\hline Biaya dinding hollowblock $\mathbf{1 m}^{\mathbf{2}}$ & $\mathbf{2 1 8 . 6 3 0 , -}$ \\
\hline Bahan dinding 11pc:3pp & $113.740,-$ \\
\hline Tenaga pasang dinding & $21.200,-$ \\
\hline Pesteran 1pc:pp, $15 \mathrm{~cm}, 2$ muka & $83.690,-$ \\
\hline
\end{tabular}

Biaya tenaga pasang dinding antara batu bata dan hollowblock lebih mahal dibanding- kan dengan biaya pasang material dinding berpengunci (Witarso, 2007).

Perhitungan tersebut memperlihatkan bahwa biaya pembuatan dinding lockbrick relatif sama dengan pembuatan dinding batu bata. Sedang dibandingkan dengan biaya dinding conblok/holowblock biayanya $24 \%$ lebih murah.

\section{KESIMPULAN DAN SARAN Kesimpulan}

Kuat tekan Lockbrick modular beton komposisi 1 pc : 4 agregat, dengan agregat berbagai komposiisi pasir, ladu, dan kerikil memenuhi syarat SNI mutu II, II, IV

Daya serap air lockbrick modular beton komposisi 1 pc : 4 agregat, dengan agregat berbagai komposiisi pasir, ladu, dan kerikil memenuhi syarat SNI mutu I.

Biaya $1 \mathrm{~m}^{2}$ pasangan dinding lockbrick modular $24 \%$ lebih murah dari biaya dinding batako.

\section{Saran}

- Untuk studi berikutnya selain uji kuat tekan, dan daya serap air hendaknya diuji geser sebagaimana persyaratan sebuah dinding.

- Lockbrick perlu dikembang dengan menggunakan beton ringan yang akan signifikan mengurangi beban struktur bangunan gedung, serta memberikan kemampuan hambat panas yang bak.

\section{UCAPAN TERIMA KASIH}

Ucapan terima kasih disampaikan kepada LPPM UNS dan Direktur Penelitian dan Pengabdian Kepada Masyarakat (DP2M) Direktorat Jenderal Pendidikan Tinggi, Kemendiknas $\mathrm{RI}$ yang telah memberikan dukungan fasilitas dan dana sehingga penelitian terlaksana dengan baik. Ucapan terimakasih juga disampaikan kepada anggota tim peneliti, mahasiswa dan teknisi laboratorium PTB PTK FKIP UNS yang telah membantu pelaksanaan penelitian. 


\section{DAFTAR PUSTAKA}

Balai Pengujian dan Informasi Konstruksi. 205. Harga Satuan Pekerjaan Bahan \& Upah Pekerjaan Konstruksi Propinsi Jawa Tengah, untuk Kota Surakarta, Edisi September 2013.

Dilorenzo, Nick. 2011. Concrete Panel Construction System, Patent Number US 7,958,687 B2, Tanggal 14 Juni 2011.

Chavoshi, Mahsa. 2011. Mechanical Properties of Soil Cement Interlocking Block, Thesis, Universiti Tenga Nasional Malaysia.

Dipohusodo. Istimawan. 1994. Struktur Beton Bertulang. Gramedia Pustaka Utama, Jakarta

Habsya C. 2010. Desain Prapabrikasi Komponen Struktur dan Komponen Dinding Bangunan Gedung, FKIP UNS Surakarta.

Habsya C. 2014. Bata Modular Berpengunci Untuk Bangunan Gedung, Pendaftaran Paten Nomor, S00201401680, Tanggal 21 Maret 2014, Dirjen HKI Kemenkumham RI.

Kaskus: archive.kaskus.co.id/thread/908330/3770

Nagy, John R and Krell, Clinton C. 2012. Modular Concrete Building. Paten US8,132,388B2. Tanggal 13 Maret 2012.

Simmons, Scott. 2000. Modular Building Materials. US Paten Number US006,088,987. Tanggal 18 Juli 2000.

SNI 6897:2008, Tata Cara Perhitungan Harga Satuan Pekerjaan Dinding untuk Konstruksi Bangunan Gedung dan Perumahan, Butir 6.18.

SNI 03-0349-1989, Bata Beton untuk Pasangan Dinding, Badan Standardisasi Nasional.

Witarso, WS. Pengembangan Interlockblock Untuk Menurunkan Biaya Konstruksi Rumah, Jurnal Permukiman Vol. 2 No. 1 Mei 2007.

Yoga. 20113. Pengaruh Abu Pembakaran Sampah Campuran Sebagai Pengganti Sebagian Agregat Halus Terhadap Karakteristik Lockbrick Moduler, Skripsi PTB FKIP UNS, Sekripsi, Desember 2013. 